Kowalska Jolanta, Kowalewski Michal. Opinions of physical education teachers about the preparation of teachers of early school education to carry out physical activities in classes I-III. Journal of Education, Health and Sport. 2020;10(5):111-117. eISSN 23918306. DOI http://dx.doi.org/10.12775/JEHS.2020.10.05.010

https://apcz.umk.pl/czasopisma/index.php/JEHS/article/view/JEHS.2020.10.05.010

https://zenodo.org/record/3827927

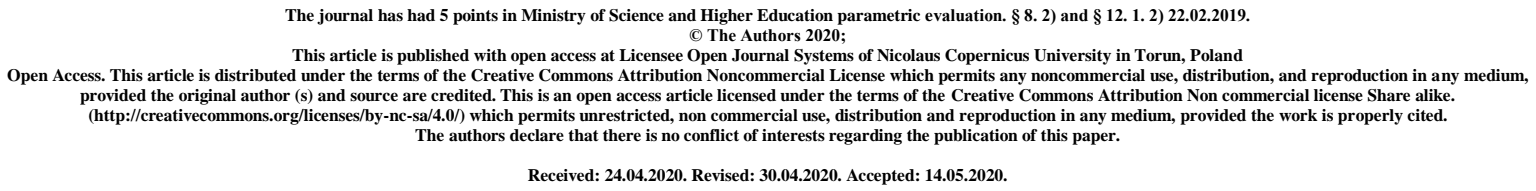

\title{
Opinions of physical education teachers about the preparation of teachers of early school education to carry out physical activities in classes I-III
}

\author{
Jolanta E. Kowalska ${ }^{1}$, Michał Kowalewski
}

\section{Summary}

Primary schooling is the most important stage in a child's development. Therefore, it is very important that the first teacher, who is an authority for a small child, is competent in all areas of education, including the conducting of the physical activities. Entrusting physical education classes to teachers of early school education is the simplest solution, but at the same time extremely difficult with serious consequences for children in the future.

Based on some of the research results presented in this article, attempts were made to describe what are the opinions of physical education teachers about the competence of early school education teachers, to conduct physical education classes. The study was conducted in 2015 during the implementation of a training course for teachers of primary schools in the Lodz region by the Laboratory of Physical and Health Education of the University of Lodz. The results of the study were based on interviews with $\mathrm{N}=30$ physical education teachers $(\mathrm{N}=$ 20 women and $\mathrm{N}=10$ men), working with classes IV-VI and participating in the training mentioned.

Keywords: integrated teaching, physical education, competence of an early school education teacher to conduct physical activities

\footnotetext{
${ }^{1}$ University of Lodz, Faculty of Educational Sciences, The Department of Physical and Health Education,mail: jolanta.kowalska@uni.lodz.pl

${ }^{2}$ University of Lodz, Faculty of Educational Sciences, The Department of Pedagogy of Childhood,mail: michal.kowalewski@uni.lodz.pl
} 


\section{Introduction}

Teaching at the first stage of education requires comprehensive knowledge, many competences as well as personality traits necessary for this profession. The article focuses on the opinions of specialists in this field, physical education teachers, regarding the competence of early school education teachers to carry out physical activities.

In addition to the general competences of the teacher, which are: didactic, caring, educational, environmental and research, one should also focus on the competence to conduct physical education lessons. In most Polish universities, students of early school education faculties have very few practical classes, that would help them in conducting physical activities. Very often, teachers in classes I-III during their first years of work at school, they conduct them based primarily on their own experience. Today, a lot is said about civilization diseases. Many of them result from the lack of physical activity among young people. It is worth noting that the disease more often affects people who are reluctant to exercise. Reluctance is born at an early school stage. This threat results from inadequate care of the education system to shape an efficient and healthy student. Many students have not received any support during the first three years of school from a teacher prepared for this - the physical education teacher. The classes are very often organized as co-educational, without separation of boys and girls ${ }^{3}$.

\section{Early school education teacher and his competences}

Teachers must be always up to date with new professional competences. They should be continuing education and attending courses. In addition, they must have the ability to quickly adapt to new conditions (changes in the education system, education or curriculum). Along with the development of the entire school society, changes in the professional and social functions of teachers are evident. The resources of teachers' knowledge that they pass on to their students are their life achievements, which include: hard, long-term work, all life's efforts. .

Jolanta Szempruch indicates that "the basic tasks that determine the quality of a teacher's work are: developing independence, developing interests, stimulating cognitive activity, developing sensitivity to values, creating opportunities to fully use the psychological possibilities of students, ensuring participation in the pedagogical work of the environment related to removing micro-defects, formulating students' life and professional plans $" 5$.

The teacher's performance of his/ her professional functions is influenced, among others, by the competences he/ she obtained during his education and preparation for the profession, including competences in conducting physical activities.

\footnotetext{
${ }^{3}$ Białek A., Fila J., Zielonka P., Physical education in the opinions of directors and teachers. Organization of education, core curriculum and assessment of students in primary schools, Instytut Badań Edukacyjnych, Warsaw 2015,file: /// C: / Users / User / Downloads / IBE-report-ee-20\% PE (1) .pdf [access: 20.02.2020], pp. 7-8, 34 .

${ }^{4}$ T. Malinowski., Teacher and society, PWN, Warsaw 1995, p. 75.

${ }^{5}$ J. Szempruch, Teacher in a changing school. Functioning and professional development, ed. Oświatowe FOSZE, Rzeszów, 2001, pp. 107-108.
} 


\section{Physical education as a school subject at the first stage of education}

During the education at the first stage of education, we deal with teaching conducted mostly by one teacher, except for religion and foreign language lessons. Physical education classes conducted by a qualified teacher are organized very seldom. In the current Regulation of February 14, 2017 on the core curriculum of general education for primary schools, we read that ${ }^{6}$ : A student attending classes 1 to 3 of primary school will have a subject called "physical education". Its task will be to acquire both knowledge of sports and health skills in three closely related fields; personal hygiene and health, motoric skills, various forms of recreation and sport. The regulation specifies in detail what skills a child should acquire in each particular field mentioned. However, it applies only to healthy people, developing according to all standards. So, if in a given class, a group includes a child with a disability or unable to perform selected exercises, or a one with posture defects, then the teacher is to prepare an individual work plan for a given child, adapted to his or her abilities.

It seems that early childhood education teachers are not properly prepared to conduct physical education classes. "Unfortunately, not too much time is devoted to this subject at pedagogical studies. Only in 12 percent of schools, in the classes 1-3, PE lessons are conducted by qualified teacher"

\section{Psychophysical development of children aged 6-10}

Eugeniusz Lazowski and Hanna Tomaszewska write: "Among children at a younger school age there is a great diversity in terms of development and physical fitness. So children of the same age differ in height, weight, physical fitness and biological maturity. Development and growth have different pace, rhythm and momentum for different individuals. " 8 .

The period between six and eight years of age is called "height jump" because the child grows very quickly during this period and his body posture changes. After the age of eight, growth stops and internal body growth begins. Slow and steady increase in body height and weight occurs. Between the ages of seven and eight, children develop larger muscles than small ones. As in the case of kindergarten children, hyperactivity persists expressed by unnecessary and rapid movements, which are not accurate. As late as between 10 and 11 years of age the bones of the wrists harden, which results in increasing the child's ability to perform tasks more accurately, such as: writing, manipulating small objects ${ }^{9}$.

Knowledge of children's psychophysical development is a very important aspect for every teacher, especially at the first stage of education. Thanks to such knowledge and the ability to use it correctly, the teacher not only educates the child in terms of increasing his

\footnotetext{
${ }^{6}$ At the time of the research, the core curriculum was in force under the Regulation of the Minister of National Education of 30.05. 2014. The majority (starting from 2019) of the core curriculum for early childhood education is includedhttps://podstawaprogramowa.pl/files/D2017000035601.pdf [Access: 02.10.2020].

${ }^{7} \mathrm{~K}$. Rymarek, start your toddler. How to conduct PE as part of early school education. PE expert materials with class,https://www.szkolazklasa.org.pl/wp-content/uploads/2016/12/rozruszaj_malucha.pdf [access: 20.02.2020], p. 1.

${ }^{8}$ E. Łazowski, H. Tomaszewska, Physical development of children in preschool and school age, including adolescence, [in:] Materials for teaching psychology, L. Wołoszynow (ed.), Series II, Tom I, Warsaw 1996, p. 12

${ }^{9}$ E. Strupińska, Biomedical foundations of physical development and education, [in:] Physical education in integrated education, S. Sulisz (ed.), WSiP, Warszawa 2000, pp. 21-28.
} 
knowledge, but also in moral, social and aesthetic terms ${ }^{10}$. It sets up studenst with tasks adequate to age and their abilities. However, psychophysical development, as well as other aspects of development, should be treated very individually and many methods of measuring and observing the child should be used, before the exercises are matched to students' abilities $^{11}$.

\section{Supporting the development of children with posture defects at the first stage of education}

Posture defects belong to the diseases of civilization and underestimating them may in the future result in the development of various diseases. In the current world, number of children with posture defects is increasing, which is largely due to a change in our lifestyle. At school, the child sits, as well as doing homework, and even when he/ she has the opportunity to relax usually chooses a computer game, social media browsing or watching TV. Years ago, children ran, climbed, spent more time with their peers at games, thanks to which they had much more physical activities.

It is very important to be aware about the high occurrence of various posture defects among young students, applying this awareness not only to parents, but also to teachers, which during individual exercises, can correct a given defect or aggravate it. In many schools, in addition to conducting regular physical education lessons, corrective classes are often conducted. Thus is very important for early school teachers to be able to recognize them. A defect detected early enough, could be corrected quickly ${ }^{12}$.

\section{Research method and material}

The aim of the presented research is to assess physical education teachers, prepare early school teachers to carry out physical activities in grades I-III.

The main research question was formulated as follows: How do the surveyed physical education teachers assess the competence of early school education teachers, to conduct physical activities at the first stage of education?

To find out the opinions of physical education teachers on this subject, a survey was conducted among $\mathrm{N}=30$ physical education teachers of primary schools in Łódź, who in 2015 taught in classes IV-VI and took part in an educational project entitled "Creator of health and physical activity", implemented by the Laboratory of Physical and Health Education of the Faculty of Educational Sciences of the University of Lodz. There were $\mathrm{N}=20$ women and $\mathrm{N}=$ 10 men.

The article presents a fragment of the research - answers to four out of 12 questions asked to physical education teachers. All respondents indicated that in their schools, only women teach classes I-III.

\footnotetext{
${ }^{10}$ M. Bondarowicz, T. Staniszewski, Fundamentals of theory of methodology of games and motion games, AWF, Warsaw 2000, p. 11.

${ }^{11}$ M. Bronikowski, Didactics of physical education, physiotherapy and sport, AWF, Poznań 2012, pp. 245-258.

${ }^{12}$ I. Galetta-Mac, Selected Issues in Posture Correction, [in:] Physical education in integrated education, S. Sulisz (ed.), WSiP, Warszawa 2000, pp. 42-58.
} 


\section{Own research results}

The surveyed physical education teachers answered the following questions of the interview questionnaire.

1. Who should teach the physical activities at the first stage of education: teacher of early school education or a PE teacher? According 29 respondents the physical activities should be led by a qualified person, i.e. a physical education teacher. They justified their statement by the fact, that they know how motoric skills develop and know the motoric needs of a child of this age. They also focus on i.e. precision of conducting the exercises not only doing them for joy and fun. At the same time, 16 respondents pointed out problems related to the proper organization of classes and the proper selection of exercises, by teachers in classes I-III. Only according to 1 person, an early school education teacher can properly conduct physical activities lessons and he/ she is well prepared to do it.

2. Do they teach physical education in classes I - III? Seven of them conduct physical education classes in grades I-III, and two of them spend one hour a week with children in such classes.

3. Are children- taught of physical education in classes I-III, by teachers of early childhood education- properly prepared to participate in physical activities in the next stage of education? In the opinion of physical education teachers, children completing the third grade of primary school are not fully prepared to participate in the next stage of education in physical education classes. Sometimes they are unable to perform basic exercises, which are the basis for learning the next, more complex motoric tasks. However, the teachers admitted that it also depends on the specific student and his actual abilities.

4. How could early school education teachers improve and broaden their competence to conduct physical activities? Respondents pointed out that early school education teachers have many opportunities for further training in conducting physical activities. They have at their disposal numerous courses, workshops or trainings, as well as qualified teachers who are willing to give guidance or can give lessons, that anyone can attend. There is also great desire to help teachers of classes I-III if they only ask for it. The respondents also mentioned the variety of needs that educators have in terms of teaching skills itself - primarily in the field of methodology for teaching rolls, throws and grips of the ball. They also pointed to the insufficient number of instruments and utensils that could diversify and support conducting games, plays and physical exercises.

\section{Conclusions}

The surveyed physical education teachers in the vast majority believe that early school education teachers are poorly prepared and are not able to conduct physical activities well with small children. Therefore, they did not very highly assess their competence to conduct physical education lessons. First of all, they believe that teachers in classes I-III do not have as much knowledge about children's motoric development and methodology of teaching individual motor skills as they do. They have problems with the proper organization of classes and selection of exercises. However, not everyone thought so. One teacher admitted that at the 
first stage of education, an early school teacher is a person who is well prepared to conduct physical education classes and positively assesses her competences.

The surveyed physical education teachers are of the opinion that they should conduct physical activity from the beginning of education of children. This is often due to the poor preparation of students for further education in motoric skills. They are qualified and have detailed knowledge that will ensure students are well prepared, to acquire skills at the next stages of education. Similar results are presented by Ewelina Gutowska-Wyrzykowska indicating that, "nearly $92.0 \%$ of physical education teachers recognized themselves - a graduate of the University of Physical Education - as a person who should direct the process of physical education at the first stage of education" ${ }^{13}$. The authors of the report for the Educational Research Institute are of a different opinion. According to the declaration of physical education teachers in their research, almost all students at the end of the first stage of education had the skills required in the core curriculum. The students' skills were rated worse in the area of ball exercises (throwing, rolling, dribbling) $)^{14}$.

Due to the fact that the surveyed teachers rated very poorly the competence to conduct physical activities in younger classes of primary school, by teachers of early school education, an important aspect is to show the possibilities of such teacher education. The system of education in studies should be changed to one, that will give teachers of early school education a wide range of knowledge in various fields and will focus more on the methodology of teaching physical activities. This will help teachers not only implement the core curriculum in physical education, but also indicate how to conduct classes, so as not to bore or discourage children from participating in physical activities. Teachers have the option of improvement. The surveyed physical education teachers also emphasized that they are open to give tips or conduct demonstration lessons. It should be noted here that in educating educators one cannot focus only on the teaching methodology, as Stefan Wołoszyn emphasized, one should opt for the "humanized model of teaching teacher's scientific culture" $^{15}$. Today we need a change in thinking about education. Just like Maciej Demel once did a maneuver of repedagogisation ${ }^{16}$ physical education, today the Ministry of National Education should take actions that will shape students' awareness, the positive impact of physical activity on health and enrich the student in motor stimuli from an early age.

It seems reasonable to question the correctness of conducting physical activities by overloaded with work, unprepared in terms of content and practicality, teachers working with children at the first stage of education. Perhaps it is worth paying attention to the idea of conducting physical activities together by a physical education teacher and a teacher of early school education - as a supporting teacher.

\footnotetext{
${ }^{13}$ K. Żegnałek, E. Gutowska-Wyrzykowska, Preparation of teachers for physical education classes at the level of early school education, http://www.czasopismoippis.up.krakow.pl/wp-content/uploads/2015/01/PPIW-9zegnalek-gutkowska-wyrzykowska_-int.pdf [access: 10.02.2020], p. 10.

${ }^{14}$ Białek A., Fila J., Zielonka P., Physical education in the opinions of directors and teachers. Organization of education, core curriculum and assessment of students in primary schools, Instytut Badań Edukacyjnych, Warsaw 2015,file: /// C: / Users / User / Downloads / IBE-report-ee-20\% PE (1) .pdf [access: 20.02.2020], p. 60.

${ }^{15}$ S. Wołoszyn S., How to educate teachers, [in:] Thoughts and remarks on physical education and sport, K. Zuchora (ed.), AWF, Warsaw 2000, p. 439.

${ }^{16} \mathrm{M}$. Demel, Peculiarities of physical education as a subject at school, [in:] Methodology of physical education, T. Maszczak (ed.), AWF, Warsaw 1992, pp. 30-37.
} 


\section{Bibliography}

Bondarowicz M., Staniszewski T., Fundamentals of theory and methodology of games and motion games, AWF, Warsaw 2000.

Białek A., Fila J., Zielonka P., Physical education in the opinions of directors and teachers. Organization of education, core curriculum and assessment of students in primary schools, Instytut Badań Edukacyjnych, Warsaw 2015,file: /// C: / Users / User / Downloads / IBEreport-ee-20\% PE (1) .pdf [access: 20.02.2020].

Bronikowski M., Didactics of physical education, physiotherapy and sport, AWF, Poznań 2012.

Demel M., Peculiarities of physical education as a subject at school, [in:] Methodology of physical education, T. Maszczak (ed.), AWF, Warsaw 1992.

Galetta-Mac I., Selected Issues in Posture Correction, [in:]Physical education in integrated education, Sulisz S. (ed.), WSziP, Warsaw 2000.

Grabowski H., Theory of physical education, WSziP, Warsaw 1997.

Łazowski E., Tomaszewska H., Physical development of preschool and school children including adolescence, [in:] Materials for teaching psychology, L. Wołoszynow (ed.), Series II, Volume I, Warsaw 1996.

Malinowski T., Teacher and society, PWN, Warsaw 1995.

Maszczak T., Physical education in a new school. Handbook for physical education students, AWF, Warsaw 2009.

Maszczak T., Education through development, "Olympic Education Center" Foundation, Warsaw 2014.

Core curriculum for early childhood education (https://men.gov.pl/wpcontent/uploads/2014/08/zalacznik_2.pdf) [access: 10.12. 2015].

Core curriculum for early school education https://podstawaprogramowa.pl/files/D2017000035601.pdf [Access: 02.10.2020].

Rymarek K., start your toddler. How to conduct PE as part of early school education. PE expert materials with class,https://www.szkolazklasa.org.pl/wpcontent/uploads/2016/12/rozruszaj_malucha.pdf [access: 20.02.2020].

Strupińska E., Biomedical foundations of physical development and education, [in:] Physical education in integrated education, S. Sulisz (ed.), WSiP, Warszawa 2000, pp. 21-41.

Strzyżewski S., The process of education in physical culture, WSziP, Warsaw 1986.

Szempruch J., Teacher in a changing school. Functioning and professional development., Wyd. Educational FOSZE, Rzeszów 2001.

Wołoszyn S., How to educate teachers, [in:] Thoughts and remarks on physical education and sport, K. Zuchora (ed.), AWF, Warsaw 2000.

Żegnałek K., Gutowska-Wyrzykowska E., Preparation of teachers for physical education classes at the level of early school education,http://www.czasopismoippis.up.krakow.pl/wpcontent/uploads/2015/01/PPIW-9-zegnalek-gutkowska-wyrzykowska_-int.pdf [access: 10.02.2020]. 